\title{
Impact of Water Temperature Fluctuation on the Health Status and Reproduction in Female Oreochromis niloticus
}

Eissa I. A. M., Nashwa S. Elias, Mona M. Ismail, Maysa H. Mohamed, and Rahma H. Eid

Dept. of Fish Diseases and Mangment, Fac. of Vet. Medicine, Suez Canal Univ, Ismailia

Dept. of Fish Diseases, Animal Health Research Institute, Dokki, Giza. Eissavet29@yahoo.com, Mona.ismail691@yahoo.com, Roka_kok020105@yahoo.com

Nashwaelias229@yahoo.com, maysa.shaker@yahoo.com,

\section{Abstract}

This research designed monitoring effect of increased water temperature on female $O$. niloticus experimentally and survey . One hundred female $O$. niloticus from private farm divided into four groups: $1 \mathrm{st} \mathrm{kept} \mathrm{at} \mathrm{room} \mathrm{temperature} \mathrm{(Control)} \mathrm{and} 3 \mathrm{kept}$ at 30,33 and $36{ }^{\circ} \mathrm{C}$ water temperatures respectively for 2 weeks. Two Survey groups collected from El monib at $27{ }^{\circ} \mathrm{C}$ (Control) and other at $36^{\circ} \mathrm{C}$ water temperature. Experimental fish suffered of nervous manifestations, suffocation, detached scales, ulcers and tail rot. Postmortem lesions included unsymmetrical friable ovaries with autolysis. Females showed highly significant decrease in B.W., WG, WH, IG, K condition, relative and absolute fecundity at all experimented groups. Survey females B.L., B.W., F.B.L., F.B.W., WG and IG showed high to moderate significant increase. Oppositely, F.O.W., K condition and absolute fecundity copied moderate to high significant decrease. Among experimental groups, albumin $\left(\right.$ at $\left.30^{\circ} \mathrm{C}\right)$, glucose and testosterone increased highly significant whereas albumin at $33 \& 36{ }^{\circ} \mathrm{C}$ and E2 at $36{ }^{\circ} \mathrm{C}$ showed highly significant decrease. Survey group registered highly significant increase in albumin, glucose and testosterone. Total proteins, globulins and E2 showed highly significant decrease. Ovaries affected by increased water temperature; worst lesions appeared in survey. Ovaries showed necrosis, clumping and perforation of the chorion, fragmentation of nucleus, or cystic atretic follicles. Liver showed swollen hepatic cells. Favorable water temperature for $O$. niloticus fish is $27 \pm 2^{\circ} \mathrm{C}$. Thus, it is recommended to use more aerators in fish ponds especially brood stocks or to be covered during summer season.

Key words: temperature, fecundity, liver and ovary. 
Introduction:

Tilapia species are very important either natural or cultured in Egyptian freshwater ecosystems. Economic importance of Tilapia is constantly increasing for their fast growth, disease resistance, different feeding habits and palatability (Dagzie, 1982). Tilapia researchers world-wide have concluded that one of the most important requirements for the advancement of Tilapia culture is the development of systems for mass production of seed (free-swimming fry, sac fry and eggs released from the female's mouth) Hughes and Behrends (1983). Tilapias were second to the carps in weight harvested from culture ponds (Lovshin, 1997). Nile tilapia, Oreochromis niloticus, being the most widely cultured tilapia in the world, due to its rapid growth, late age of sexual maturity and planktivorous feeding habits (Gonzalez, 1997). Moreover, it constitutes a considerable part in the annual fish production of the Northern Delta Lakes of Egypt (Shakweer and Abbas, 2006).

Water temperature is a fundamental physical regulatory factor in the lives of fishes and this effect is expressed particularly strongly in the control of all reproductive processes from gamete development and maturation, ovulation,

spermiation, spawning, embryogenesis and hatching, to larval and juvenile development and survival. In reproductively mature adults, temperature is generally considered to be a secondary due to photoperiod in phasing reproductive seasonality but it has a major role in synchronizing the final stages of reproductive maturity, and also in truncating reproductive episodes (Pankhurst and Porter 2003) and they also said that most temperate teleost's show seasonality of reproduction and this is usually more sharply defined at higher latitudes where there is greater amplitude of seasonal variation, and consequently greater requirement for seasonal synchronization of reproduction. The effects of temperature can be differentially expressed depending on when in the annual thermal cycle spawning normally occurs. The goal of this study is to shed light on the mismatch between rise of water temperature experimentally (at three water temperatures 30,33 and $36^{\circ} \mathrm{C}$ ) and in survey on $O$. niloticus fecundity together with biochemical parameters (total protein, albumin, globulin, glucose, estradiol and testosterone) and histopathological alternations.

\section{Materials and methods}




\section{Fish:}

a. A total number of 100 female Oreochromis niloticus with an average body weight $100 \pm 20 \mathrm{~g}$. were collected alive from a private farm at Wadi El-Natroon in summer 2018 and transported into large plastic containers supplemented with battery aerators, to Biology Unit - Fish Diseases Dept. at Animal Health Research Institute, Dokki.

b. A total of 50 apparently healthy Oreochromis niloticus with an average body weight $100 \pm 20 \mathrm{~g}$ were collected from EL-monib to make survey at different water temperatures 27 $\pm 2{ }^{\circ} \mathrm{C}$ (control) and $36{ }^{\circ} \mathrm{C}$.

\section{Aquaria:}

Fish were kept 2 weeks for acclimation in fully prepared glass aquaria supplied with electric air pumps for continuous aeration and heaters. Experimental design:

80 fish were divided into 4 groups (20 each). In 3 groups, water temperature was adjusted at 30,33 and $36{ }^{\circ} \mathrm{C}$ using heaters. Temperature was raised gradually at a rate of $1{ }^{\circ} \mathrm{C} /$ day in order to avoid thermal shock. The 4th group (control group) was kept at a temperature $27 \pm 2$ ${ }^{\circ} \mathrm{C}$. The experiment lasted for 2 weeks.

Two survey groups (20 each) were collected from River Nile (EL-Monib) at water temperature $27 \pm 2{ }^{\circ} \mathrm{C}$ (Control survey) and $36{ }^{\circ} \mathrm{C}$ (Survey).
Fish Growth Measurements:

For each fish body Length (B. L.) , body Weight (B.W.), ovarian weight (WG) and hepatic weight (WH) were measured for each fish separately in experiment and survey groups.

\section{Morpho - anatomical Parameters:}

For each fish Gonado-somatic Index $\left(\mathrm{I}_{\mathrm{G}}\right)$ and Hepato-somatic Index $\left(\mathrm{I}_{\mathrm{H}}\right)$ indices as well as Condition factor (K) were calculated according to Sun and

Pankhurst (2004).

Clinical examination:

Ovaries and liver of each fish were examined macroscopically to detect any abnormality and experimented fish were kept under investigation for any abnormal behavior.

\section{Survival rate:}

It was calculated for each group Fecundity evaluation:

Absolute fecundity and relative fecundity were calculated for each fish according to Nashwa (2009).

Serum was carefully collected in clean dry Epindorff tubes from each fish separately and preserved at $-4{ }^{\circ} \mathrm{C}$ until analysis.

Biochemical Investigation:

-Serum Total protein (T.P) and Albumin were estimated for each fish according to Young DS, (1995).

-Serum Globulin was estimated for each fish by subtracting Albumin from Total proteins. 
-Serum Glucose was estimated for each fish according to Tietz (1995 a)

-Sex hormones levels: concentration of testosterone (T) and estradiol (E2) hormones were measured for each fish by ELIZA kits according to Tietz (1995 b and c).

Histopathological

\section{Examination:}

Ovaries and liver samples from each group under test were kept in Bouin's solution for 48 hours before being prepared, for histopathology (Takashima and Hibiya, 1995).

Statistical Analysis: The obtained data were statistically analyzed according to SPSS 14 (2006) using T test.

\section{Results:}

Clinical signs and postmortem

\section{findings:}

Clinical signs: At 33 and $36^{\circ} \mathrm{C}$, fish suffered from nervous manifestation, suffocation as well as abnormal swimming, abnormal skin pigmentation, detached scales, skin ulcer and tail rot.

Postmortem lesions: Unsymmetrical ovaries at both 33 and $36^{\circ} \mathrm{C}$ which were sometimes friable with autolysis.

At $33^{\circ} \mathrm{C}$ showing enlarged oedematus ovaries.

Effect of Temperature on $O$. niloticus (experimental and survey female)

Survival rate for each experimental group was tabulated in Table (1).

The results of growth measurements, morpho anatomical parameters, relative fecundity and absolute fecundity of the experimental and survey groups were tabulated in Tables (2) and (3).

Results of the biochemical parameters for experimented and survey groups were tabulated in Table (4).

(Table 1): Showing the Survival rate of Female O.niloticus

\begin{tabular}{|c|c|c|c|}
\hline Temp. ${ }^{\circ} \mathrm{C}$ & Initial number & Final Number & Survival rate \% \\
\hline 30 & 20 & 17 & 85 \\
\hline 33 & 20 & 14 & 70 \\
\hline 36 & 20 & 11 & 55 \\
\hline
\end{tabular}


(Table 2) Comparison between female growth measurements and fecundity at different examined temperatures (Mean \pm S.D.)

\begin{tabular}{|c|c|c|c|c|c|}
\hline \multicolumn{2}{|c|}{ Reproductive parameter } & \multirow{2}{*}{$\begin{array}{c}\text { Control } \\
21 \pm 0.7\end{array}$} & \multirow{2}{*}{$\frac{\text { At } 30^{\circ} \mathbf{C}}{20 \pm 2}$} & \multirow{2}{*}{$\frac{\mathbf{A t ~}^{33^{\circ} \mathbf{C}}}{19.9 \pm 1.4}$} & \multirow{2}{*}{$\frac{\text { At } \mathbf{3 6}^{\circ} \mathbf{C}}{20.6 \pm 1.4}$} \\
\hline \multirow{4}{*}{$\begin{array}{c}\text { Growth } \\
\text { Measurement }\end{array}$} & B.L $(\mathrm{cm})$ & & & & \\
\hline & B.W (g) & $130.5 \pm 1.2$ & $105.8 \pm 2 * * *$ & $99.5 \pm 1 * * *$ & $115 \pm 3$ \\
\hline & WH (g) & $3.3 \pm 0.4$ & $1.66 \pm 0.4 * * *$ & $1.5 \pm 0.4 * * *$ & $1.36 \pm 0.3^{* * *}$ \\
\hline & WG (g) & $3.5 \pm 0.2$ & $2.1 \pm 0.9 * * *$ & $4.25 \pm 1.4 * * *$ & $2.2 \pm 0.5^{* * *}$ \\
\hline \multirow{3}{*}{$\begin{array}{c}\text { Morpho } \\
\text { anatomical } \\
\text { Parameter }\end{array}$} & $\mathrm{I}_{\mathrm{G}}$ & $4.8 \pm 0.3$ & $2.08 \pm 0.9 * * *$ & $3.8 \pm 1.5^{* * *}$ & $1.92 \pm 0.7 * * *$ \\
\hline & $\mathrm{I}_{\mathrm{H}}$ & $1.5 \pm 0.1$ & $1.62 \pm 0.2$ & $1.67 \pm 0.2$ & $1.32 \pm 0.2$ \\
\hline & $\mathrm{K}$ & $1.7 \pm 0.1$ & $1.38 \pm 0.2 * * *$ & $1.31 \pm 0.1 * * *$ & $1.5 \pm 0.3 * * *$ \\
\hline \multirow{3}{*}{$\begin{array}{l}\text { Relative } \\
\text { Fecundity }\end{array}$} & FBL & $1325 \pm 9$ & $1289.4 \pm 2$ & $1211.5 \pm 2$ & $1297.6 \pm 2$ \\
\hline & FBW & $1695 \pm 6$ & $824.6 \pm 9 * * *$ & $700.6 \pm 1 * * *$ & $822 \pm 2 * * *$ \\
\hline & FOW & $1059 \pm 5$ & $836.5 \pm 2 * * *$ & $1144 \pm 5 *$ & $656 \pm 1 * * *$ \\
\hline $\begin{array}{c}\text { Absolute } \\
\text { Fecundity }\end{array}$ & T.R Eggs & $2585 \pm 5$ & $1143 \pm 8 * * *$ & $733 \pm 2 * * *$ & $684 \pm 3^{* * *}$ \\
\hline
\end{tabular}

$\mathrm{N}=10 *$ P $<0.05 * * \mathrm{P}<0.01 * * * \mathrm{P}<0.001$

(Table 3) Comparison between female growth measurements and fecundity of survey at temperature $36^{\circ} \mathrm{C}($ Mean \pm S.D. $)$

\begin{tabular}{|c|c|c|c|}
\hline \multicolumn{2}{|c|}{ Reproductive parameter } & Control & Survey \\
\hline \multirow{4}{*}{$\begin{array}{c}\text { Growth } \\
\text { Measurements }\end{array}$} & B.L $(\mathrm{cm}) \quad$ B.L. & $19.4 \pm 1$ & $23.3 \pm 3 * * *$ \\
\hline & B.W. (g ) & $95 \pm 6$ & $133 \pm 4 * * *$ \\
\hline & $\mathrm{W}_{\mathrm{H}}(\mathrm{g})$ & $1.67 \pm 0.7$ & $1.3 \pm 0.2$ \\
\hline & $\mathrm{W}_{\mathrm{G}}(\mathrm{g})$ & $2.696 \pm 1$ & $4.25 \pm 0.7 * *$ \\
\hline \multirow{3}{*}{$\begin{array}{c}\text { Morpho- } \\
\text { anatomical } \\
\text { Parameters }\end{array}$} & $\mathrm{I}_{\mathrm{G}}$ & $3.03 \pm 0.9$ & $4.39 \pm 0.4 * *$ \\
\hline & $\mathrm{IH}_{\mathrm{H}}$ & $1.75 \pm 0.6$ & $1.12 \pm 0.1$ \\
\hline & $\mathrm{K}$ & $1.3 \pm 0.1$ & $1.088 \pm 0.2 * * *$ \\
\hline \multirow{3}{*}{ Relative Fecundity } & FBL & $1147 \pm 1$ & $1599 \pm 4 * * *$ \\
\hline & FBW & $705.79 \pm 5$ & $1065 \pm 1 * * *$ \\
\hline & FOW & $1130.1 \pm 1$ & $960 \pm 7 * *$ \\
\hline Absolute Fecundity & T.R Eggs & $1226.26 \pm 6$ & $816 \pm \quad 7 * * *$ \\
\hline
\end{tabular}

$\mathrm{N}=10 \quad * \mathrm{P}<0.05 \quad * * \mathrm{P}<0.01 \quad * * * \mathrm{P}<0.001$ 
(Table 4): Comparison between female biochemical parameters at the different examined temperatures and the survey with the control (Mean \pm S.D.)

\begin{tabular}{|c|c|c|c|c|c|}
\hline $\begin{array}{c}\text { Biochemical } \\
\text { parameters }\end{array}$ & Control & At $30^{\circ} \mathbf{C}$ & At $33^{\circ} \mathbf{C}$ & At $36^{\circ} \mathbf{C}$ & Survey group \\
\hline $\begin{array}{c}\text { Total proteins } \\
\mathrm{mg} / \mathrm{dl}\end{array}$ & $5.01 \pm 1.16$ & $4.14 \pm 1.13$ & $4.90 \pm 1.01$ & $4.65 \pm 1$ & $3.44 \pm 0.10^{* * *}$ \\
\hline Albumin mg/dl & $0.55 \pm 0.04$ & $\begin{array}{c}1.60 \pm \\
0.66 * *\end{array}$ & $0.28 \pm 0.17 * * *$ & $0.34 \pm 0.11^{* * *}$ & $1.32 \pm 1.07 * * *$ \\
\hline Globulin mg/dl & $4.46 \pm 1.16$ & $2.54 \pm 1.30$ & $4.62 \pm 1.03$ & $4.31 \pm 0.90$ & $2.12 \pm 1^{* * *}$ \\
\hline Glucose $\mathrm{mg} / \mathrm{dl}$ & $24.5 \pm 8.8$ & $39.6 \pm 1$ & $78 \pm 3 * * *$ & $61.8 \pm 1 * * *$ & $50.7 \pm 4.6^{* * *}$ \\
\hline Estradiol $\mu \mathrm{g}$ & $1108 \pm 13$ & $1103 \pm 5$ & $1109 \pm 4$ & $1002 \pm 2 * * *$ & $1008 \pm 1 * * *$ \\
\hline Testosterone $\mathrm{Pg}$ & $15.9 \pm 1$ & $\begin{array}{c}17.7 \pm 0.2 \\
* * *\end{array}$ & $\begin{array}{c}17.2 \pm 0.3 \\
* * *\end{array}$ & $18 \pm 0.1 * * *$ & $17.5 \pm 0.3 *$ \\
\hline
\end{tabular}

$\mathrm{N}=10 \quad * \mathrm{P}<0.05 \quad * * \mathrm{P}<0.01 \quad * * * \mathrm{P}<0.001$

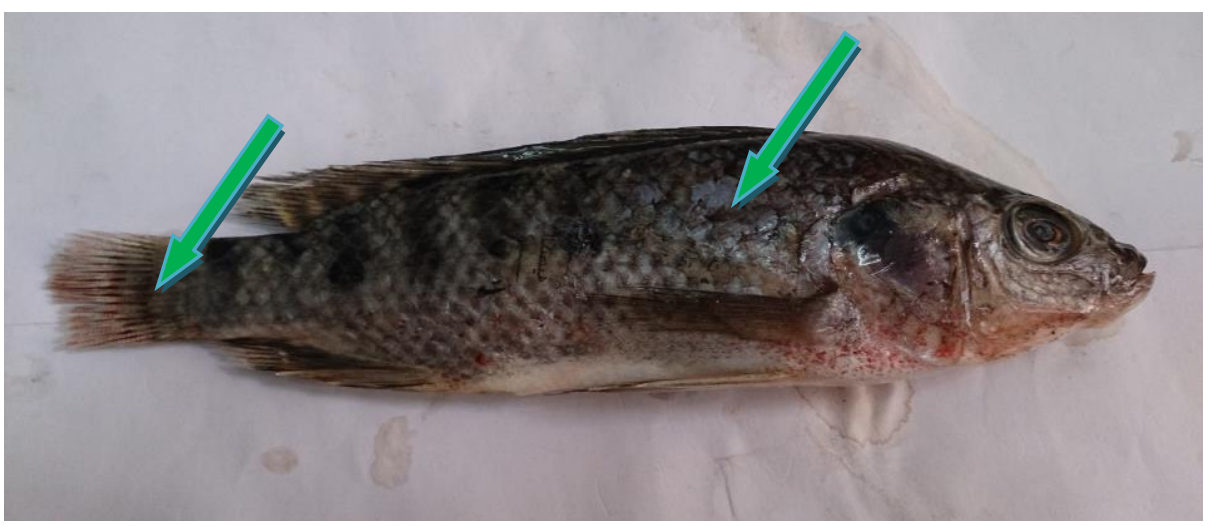

Photo (1): O. niloticus exposed to high water temperature $\left(33^{\circ} \mathrm{C}\right)$ showing skin ulceration and tail rot.

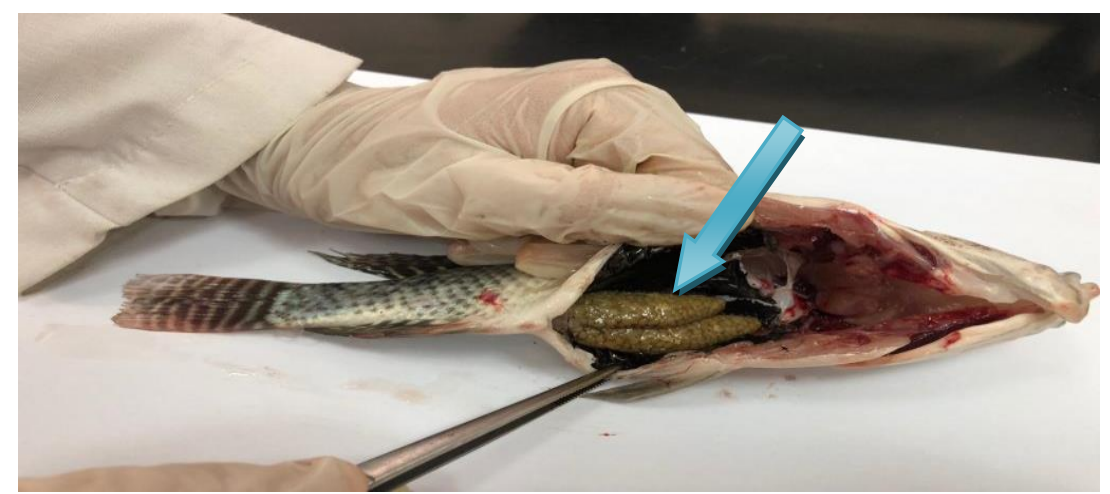

Photo (2): $\boldsymbol{O}$. niloticus exposed to high water temperature $\left(36^{\circ} \mathrm{C}\right)$ showing asymmetrical ovaries. 


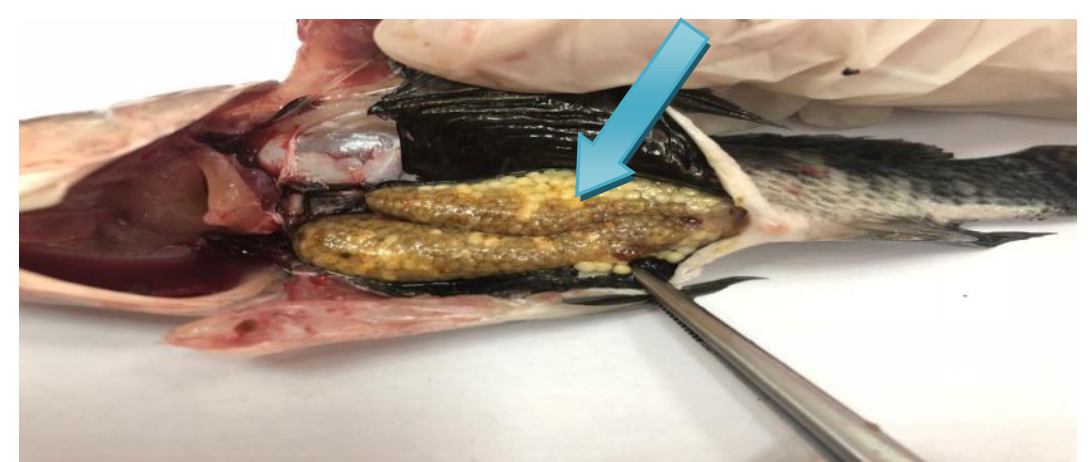

Photo (3): O. niloticus exposed to high water temperature $\left(33^{\circ} \mathrm{C}\right)$ showing enlarged ovaries.
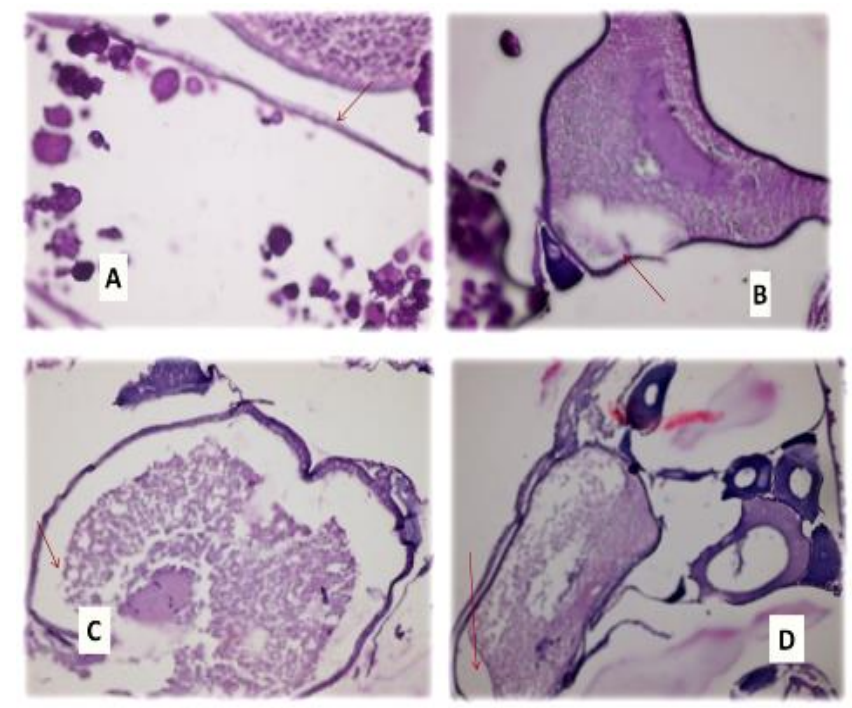

Plate 1(H\&E stain)

a. ovaries showing foccal areas of necrosis in the ovarian stroma $* 200$ b. At survey ovaries showing necrosis in the ovarian stroma with oedema $* 200$

c. At $36^{\circ} \mathrm{c}$ ovaries have slight proliferative changes in the granulosa of oocytes with separation of follicular layers from oocytes. *200 d. At $33^{\circ} \mathrm{c}$ atretic follicles characterized by stretched follicular wall, configuration of granulosa cells without dehydration of follicular fluid. $* 400$ 

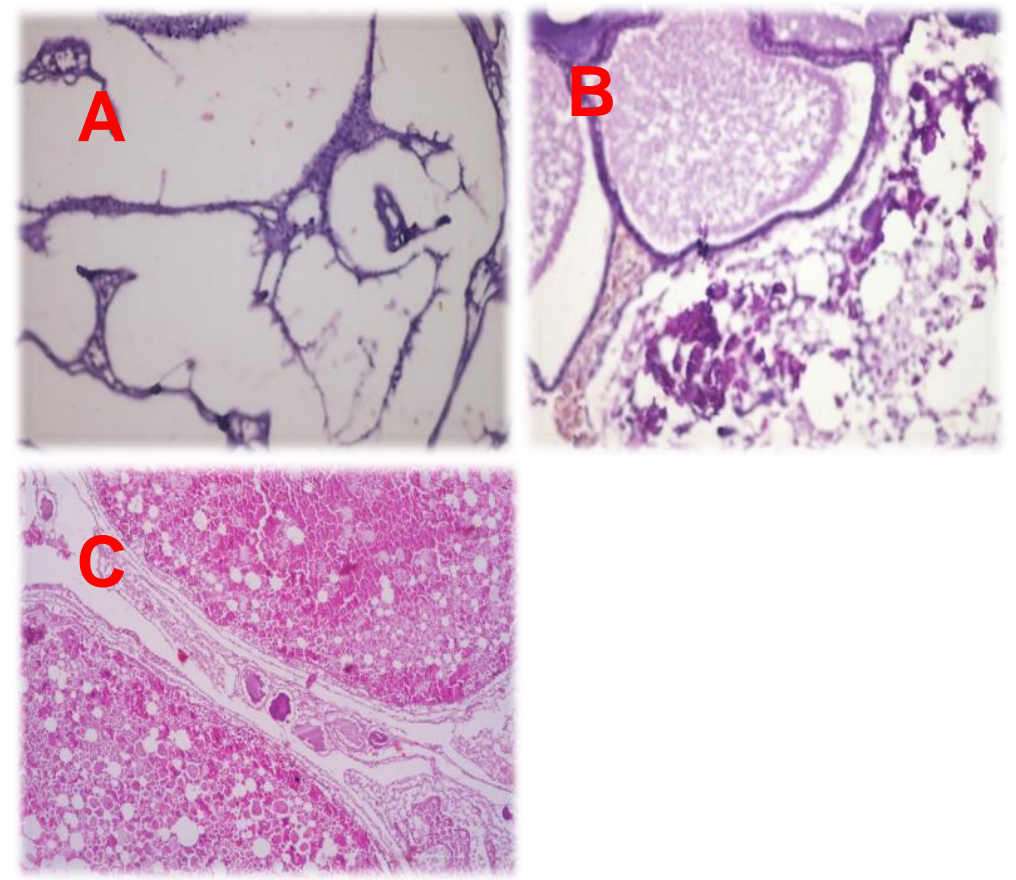

Plate 2: (H\&E stain)

a. At $36^{\circ} \mathrm{c}$ oocytes in contractive or obliterative atresia characterized by dehydration of follicular fluid $* 200$

b. At $30^{\circ} \mathrm{c}$ ovaries with oocytes collapsed showing abnormal irregular shapes $* 200$ c. Control ovary $* 400$
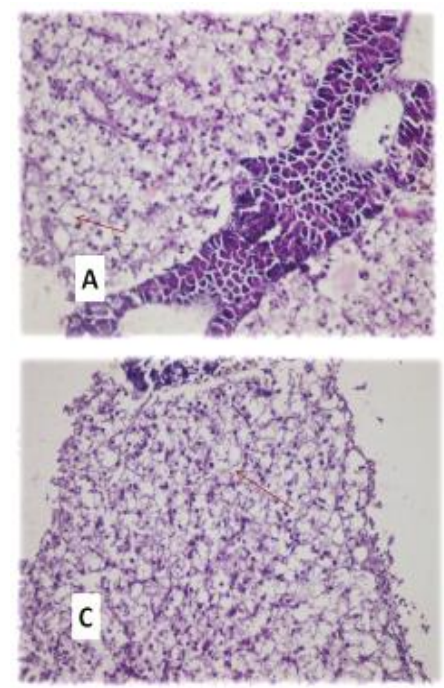
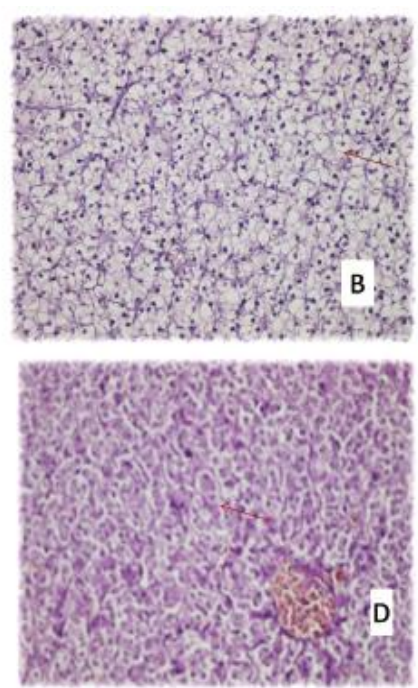

Plate 3: (H\&E stain)

a. At $30^{\circ} \mathrm{C}$ and $33^{\circ} \mathrm{C}$ liver The hepatic cells showing vacuolar degeneration $* 200$ 
b. A at $30^{\circ} \mathrm{C}$ and $33^{\circ} \mathrm{C}$ The hepatic cells appeared swollen with clean cytoplasm, their nuclei near wall of affected cells $* 200$

c. At survey hepatic cell appeared vacuolar with ruptured hepatic wall showing aphthae formation* 200

d. At survey hepatic cells appeared in the form of adenoid formation*200
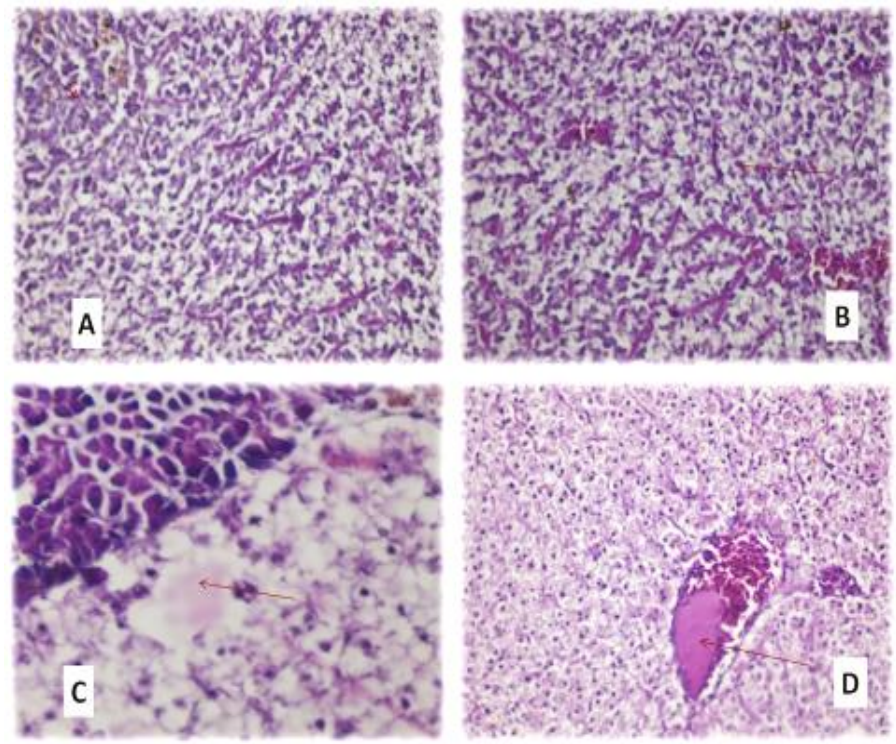

Plate 4: (H\&E stain)

a. At $30^{\circ} \mathrm{C}$ liver showing mild congestion in hepatic blood vessels. $* 200$

b. At $33^{\circ} \mathrm{C}$ liver showing mild congestion in hepatic bl. Vessels \&sinusoids $* 200$

c. At survey male liver revealed oedema and multiple degrees of necrosis. $* 200$

d. At $36^{\circ} \mathrm{C}$ liver showing congestion in hepatic blood vessels with hemolysed blood $* 200$ 

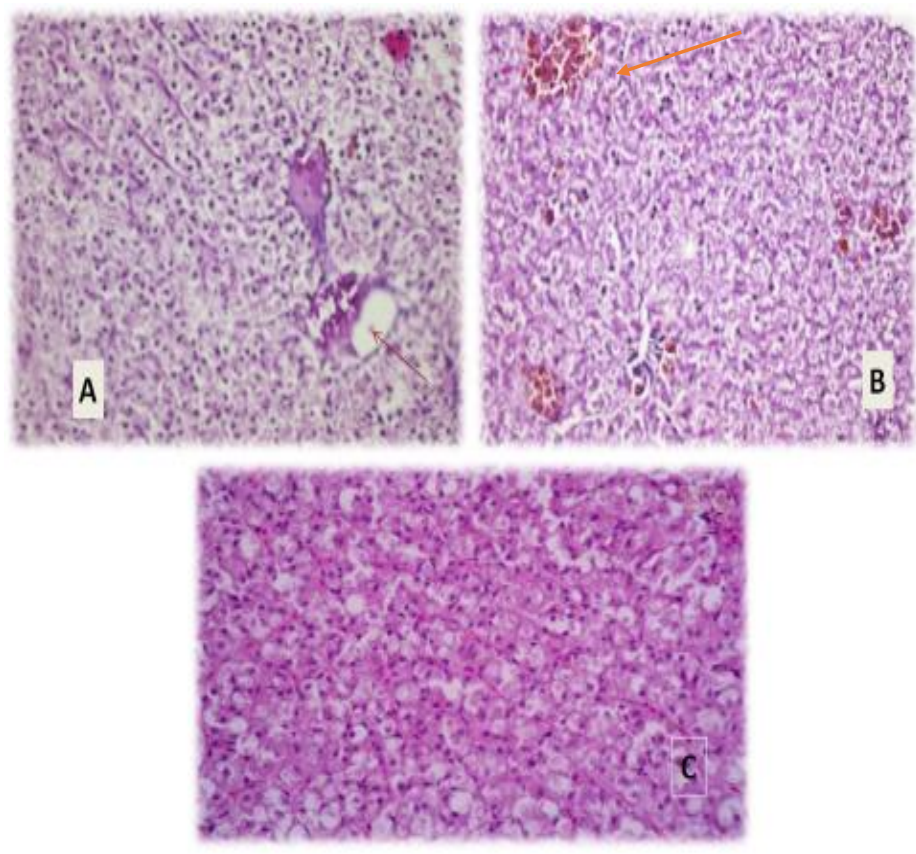

Plate 5: (H\&E stain)

a. At $36^{\circ} \mathrm{C}$ hepatic parenchyma showing hemolysed blood*200

b. At $36^{\circ} \mathrm{C}$ liver showing hyperplasia of bile duct with collongitis beside aggregation of melanomacrophage cells in hepatic parenchyma*200

c. Control liver. $* 200$

\section{Discussion}

Temperature being one of the most important ecological factors controlling and influencing all patterns of various main vital processes (respiration, growth, energetics, physiological behavior, reproductive performance and fecundity). Temperature influences on aquatic organism s are performed at constant temperatures forecasted as optimal.

O. niloticus fish exposed in this research to high temperatures showed nervous manifestation which began mild at $\left(33^{\circ} \mathrm{C}\right)$ and reached its utmost severity at $\left(36^{\circ} \mathrm{C}\right)$. This agreed with Sherif and Soad (2013) who proved that fish subjected to temperature $35^{\circ} \mathrm{C}$ showed off food, emaciation, nervous manifestation, erratic movement. Moreover, Zakia et al. (2007) proved that Oreochromis niloticus at $33^{\circ} \mathrm{C}$ showed surface swimming and grouping at the corner. While at $37-40{ }^{\circ} \mathrm{C}$ they exerted mouth breath due to decreased dissolved oxygen with increased opercular movement 
and hemorrhage on the whole body.

Temperature affects the solubility of oxygen in the waters, Malini et al. (2018), therefore the higher the temperature will lead to a lower oxygen solubility rate.

Dissolved oxygen decreased with increasing temperature in this research which appeared in accordance with Zvavahera et al. (2018) that dissolved oxygen concentration in Tilapia of less than $3 \mathrm{mg} / 1$ are stressful accompanied with fish mortalities. They added that solubility of oxygen in fish ponds decreased as temperature increased. Thus, the researcher used to measure daily dissolved oxygen and adjust it through increasing aerators.

Khater et al. (2017) had registered mortality rates 14.09 and $14.28 \%$ at water temperature 30 and $35^{\circ} \mathrm{C}$ respectively in Nile tilapia after one-week exposure which increased with increase of exposure period. Baras et al. (2001) proved that mortality rate in Nile tilapia exposed to different degrees of temperature $\left(20-40^{\circ} \mathrm{C}\right)$ mainly affected females. This was approved in this research where survival rate decreased with increase of temperature.

However, Jeremy et al. (1996) showed that survival rate of Oreochromis niloticus at $32^{\circ} \mathrm{C}$ was non-significant, whereas Baras et al. (2001) registered survival rate at $37^{\circ} \mathrm{C}$ ranged from $41.9-74 \%$ of Nile tilapia reared at $27-33^{\circ} \mathrm{C}$. Also, Pandit and Nakamura (2010) proved that survival rate of Nile tilapia was reduced at $35^{\circ} \mathrm{C}$ and $37^{\circ} \mathrm{C}$. Also, Lopez et al. (2018) proved that an abrupt thermal change (chronic heat stress) of more than $4{ }^{\circ} \mathrm{C}$ induced $50 \%$ mortality in Pacific Sardine fish. In agreement, survival rate of females decreased with temperature increase reaching $55 \%$ at $36^{\circ} \mathrm{C}$.

In this study, $\mathrm{K}$ condition of females $O$. niloticus registered a highly significant drop influenced by the three experimented increased degrees of water temperature and the survey group which might be referred to Getso et al. (2017) opinion that the highest $\mathrm{K}$ values are reached in species if the fish is fully mature, and have higher reproductive potentiality.

Jeremy et al. (1996) showed that $\mathrm{K}$ condition of Oreochromis niloticus at $28^{\circ} \mathrm{C}$ and $32^{\circ} \mathrm{C}$ was highly significant than that at $24^{\circ} \mathrm{C}$. Jin et al. (2015) presented $\mathrm{K}$ values as a parameter to estimate the characteristics of fish body structures. Moreover, condition factor $(\mathrm{K})$ of a fish as per Datta et al. (2013) reflects physical and biological circumstances and fluctuations by interaction among feeding 
conditions, parasitic infections and physiological factors. This also indicates the changes in food reserves and therefore an indicator of the general fish condition. Therefore, information on condition factor can be vital to culture system management because they provide the producer with information of the specific condition under which organisms are developing.

Getso et al. (2017) added that condition factor is an index reflecting interaction between biotic and abiotic factors in the physiological conditions of fishes. Jisr et al. (2018) defined the $\mathrm{K}$ condition as the wellbeing of the species influenced by different biological and environmental factors. It provides information about the growth pattern, general health, habitat conditions, life history, fish fatness and condition, as well as morphological characteristics of the fish.

At $30^{\circ} \mathrm{C}$ degree of water temperature females registered highly significant decrease in body weight (B.W), ovarian weight (Wg), $\mathrm{K}$ condition, relative fecundity to body weight (FBW), gonadal relative fecundity (FOW) which was attributed to ovaries with oocytes collapsed showing abnormal irregular shapes (plate $2 \mathrm{~b}$ ). These findings were the result for the highly significant decrease in absolute fecundity (T R Eggs).

Degree $33^{\circ} \mathrm{C}$ exerted more severity in a different picture. Females showed highly significant drop in body weight (B.W), gonado-somatic index (Ig), $\mathrm{K}$ condition and relative fecundity to body weight (FBW) and absolute fecundity ( $\mathrm{T} R$ Eggs). On the contrary, ovarian weight $(\mathrm{Wg})$ and the ovarian relative fecundity (FOW) proved a highly significant increase. This was approved by atretic follicles characterized by stretched follicular wall, string head configuration of granulosa cells without dehydration of follicular fluid (plate $1 \mathrm{~d}$ ). Primary reproductive investment is represented by gonadal weight and gonado-somatic index which is an indicator of somatic and reproductive measurement of mature fish, Malavasi et al. (2004).

Degree $36^{\circ} \mathrm{C}$ of water temperature expressed more severity as highly significant drop in gonadal weight $(\mathrm{Wg})$, its relative fecundity (FBW) as well as absolute fecundity ( $\mathrm{T} R$ Eggs). This was approved by oocytes in contractive or obliterative atresia characterized by dehydration of follicular fluid (plate 2 a). In addition, other ovaries revealed slight proliferative changes in the granulosa of oocytes with 
separation of follicular layers from oocytes (plate $1 \mathrm{c}$ ).

Jeremy et al. (1996) showed that body weight of $O$. niloticus at $28^{\circ} \mathrm{C}$ was significantly decreased than that at $24^{\circ} \mathrm{C}$. In addition, Zakia et al. (2007) had proved that body weight of $O$. niloticus decreased significantly with temperature increase. On the contrary, Khater et al. (2017) proved that body weight of Nile tilapia fry increased with the water temperature increase. Also, Al - Deghayem et al. (2017) proved that gonadosomatic index (Ig) of Clarias gariepinus decreased in males at $28^{\circ} \mathrm{C}$ and $32^{\circ} \mathrm{C}$ and in females at $32^{\circ} \mathrm{C}$ only. This might be a logic explanation for the highly significant drop in gonado-somatic index (Ig) of females at the 3 experimented degrees of water temperature.

El-Ashram (1999) had proved that since production of egg was the dominant function of an ovary, thus a close relationship could be expected between the ovarian weight and number of well matured ova. Consequently, this expected relationship was positively proved during the experimented degrees $30^{\circ} \mathrm{C}$ and $36^{\circ} \mathrm{C}$ only. Whereas the opposite happened with the experimented degree $33^{\circ} \mathrm{C}$ and the survey group.

Influenced by Sun and Pankhurst (2004) opinion, the researcher in this study found the highly significant drop in body weight (B.W) and its relative fecundity (F.B.W) in the three experimented degrees of water temperature a logic explanation for the mobilization of a great portion of energy in reproductive performance forming an interaction between fish growth and reproduction specially during oogenesis and ovulation.

Absolute Fecundity was defined by Gerking (1978) as the number of ripening eggs found in the female just prior to spawning. This fecundity of individual fish, called absolute fecundity (T.R. Egg No.) is the action of yolk material (vitellogenin) uptake by the perifollicular cells expressed as the formation of well matured ova filled with vitellogenin. This opinion appeared the result for the highly significant decrease in absolute fecundity (T.R.Eggs No.) in all experimented degrees of water temperature. This was approved by ovaries showing foccal areas of necrosis in the ovarian stroma (plate 1 a). In accordance, Kumar et al. (2013) had proved that temperature anomalies might interfere with hormonal regulation of gametogenesis which leads to regression of gonads as well as gonadal malfunctions.

Concerning the survey, it was proved a correlation between increase in water temperature 
and significant increase in fish body length (B.L), gonads weight (Wg) and accordingly the fecundity related to body len gth (F.B.L) and gonadal weight (FOW). Pathological examination of ovaries showed that some ovaries were characterized by oedema (plat 1 b). This might be opposite to Mahmoud and Allam (2002) who proved a negative correlation between fish gon ads and their body length.

Proteins are involved in the architecture and physiology of the cell and in cell metabolism. Blood serum proteins were defined by Moustafa (1999) to be a fairly biochemical system, precisely reflecting the condition of the organism and its physiology under the influence of internal and external changes. Zeynep et al. (2017) showed increase total protein in Black sea trout due to acute thermal stress. Thermal stress is associated with heat shock protein, Nadirah et al. (2017). They added that total protein of red hybrid tilapia slight decreased with increased degree and exposure duration to thermal stress in agreement, in this study, total protein levels registered non-significant drop among the 3 experimental temperature degrees, which became highly significant in survey group. This was approved with Lucas et al.
(2019) who had registered the lowest value for total plasma protein in females Lophiosilurus alexandri at $29^{\circ} \mathrm{C}$. This result was attributed to the pathological changes appeared in the liver. The hepatic cells appeared swollen with clean cytoplasm, their nuclei near wall of affected cells (vacuolar degeneration) as (plate $3 \mathrm{a}, \mathrm{b}$ ). Other slides showed mild congestion in hepatic blood vessels and sinusoids (plate 4 a, b).

At $36^{\circ} \mathrm{C}$ degree of water temperature some liver showed hyperplasia of bile duct with collongitis beside aggregation of melanomacrophage cells in hepatic parenchyma (plate $5 \mathrm{~b}$ ). Others showed congestion in hepatic blood vessels with hemolysed blood (plate $4 \mathrm{~d}$ ).

In some examined samples of survey group hepatic appeared vacuolar with ruptured hepatic wall showing aphthae formation (plate $3 \mathrm{c}$ ) or hepatic cells appeared in the form of adenoid formation (plate $3 \mathrm{~d}$ ).

Albumin in this study at the two experimented degrees $33^{\circ} \mathrm{C}$ and $36^{\circ} \mathrm{C}$ of water temperature was highly significantly dropped which might be explained by Kovyrshina and Rudneva (2012) as a negative correlation between fish age and albumin concentration. They added that it was attributed with the agerelated changes of metabolism, 
liver function which is the site of albumin production and albumin transport function. Albumin in fish is involved in metabolism and plays an important role in transport functions of exogenous chemicals and endogenous metabolites Kovyrshina and Rudneva (2012). Thus, albumin determination in fish plasma or serum is considerable diagnostic tool which reflects the health of the animal, liver function, metabolic status and stress conditions. They added that their studies have been shown that fish physiological status, age, season and habitats influenced on serum protein properties, especially albumin. According to Andreeva (2010) seasonal dynamics of blood albumin level had a feedback relation with the protein synthesizing activity of hepatocytes. This is assisted by the hepatopancreatic duct showing multiple degrees of necrosis (plate $4 \mathrm{c}$ ).

The survey group recorded highly significant increase in albumin level. This could be explained according to Baker (2002) by the induction of albumin synthesis in spawning time because it plays an important role in transport function of various components needed for gonads formation and eggs development. In addition, it was marked that at the period of fish maturation and reproduction the physical and chemical properties of albumin including electrophoretic mobility were changed.

Baker (2002) had proved that Albumin binds and transports steroid hormones, including sex hormones.

The author found the seasonal factor a second explanation for the albumin increase in survey group which was collected in summer season according to Kovyrshina and Rudneva (2012) who proved that albumin concentration was significantly higher in fish caught in summer. Temperature dependence of glucose concentration in toadfish blood had proved a mechanism by which temperature exerted its effect on blood sugar, Silver and Shenk (1968).

Under the condition of stress, Ray and Sinha (2014) proved that fish body immediate responses recognized as primary and secondary responses. Secondary responses occur as a consequence of the released stress hormone, causing changes in the blood and tissue chemistry e.g. an increase in plasma glucose.

This entire metabolic pathway produces a burst of energy to prepare the fish for an emergency situation. Biswas et al. (2002) reported increase glucose level in red sea bream accompanied with increased water temperature. While 
Zaragoza et al., (2008) defined glucose as a good indicator for thermal stress which was altered in Oreochromis mossambicus acclimated at $24{ }^{\circ} \mathrm{C}, 28^{\circ} \mathrm{C}$ and $32^{\circ} \mathrm{C}$.

Sherif \& Soad (2013) claimed that under stress, fish rapidly consume glucose as the main function of the central nervous system is maintaining hemostasis and with peak activity of fish, glucose increase by almost 30 - fold. Nakanon et al. (2014) found that increased temperature caused increased glucose level in Salmon. In stress blood glucose is elevated as a result of both glycogenolysis and gluconeogenesis, Ray and Sinha (2014). Moreover, Rebl et al. (2018) had proved that acute temperature rise resulted in slight increase in glucose level. In accordance, this study explained the highly significant increase of glucose level in females $O$. niloticus among the three examined degrees of temperature and the survey group as a secondary physiological response for energy use which is involved in innate defense mechanism according to Zeynep et al. (2017).

Reproduction in fish is hormonal regulation whereas the main hormones are gonadotropins and gonadal steroids including androgens
(Testosterone and its derivatives) and estrogens (estradiol and its derivatives) secreted from gonads Sulistyo et al. (2000). They specified steroids role for spermatogenesis and spermiation in males and oogenesis to final oocyte maturation in females. Estradiol in females regulate steps of oocyte development as well as its vitellogenic activity in ovaries, Barannikova et al. (2004) had proved its role in stimulating liver to produce the yolk precursor protein (exogenous vitellogenin) which is incorporated into the developing oocytes. In addition estradiol in ovaries plays an initiative role to secret endogenous vitellogenin till final ova maturation. On the contrary, estradiol level showed significant drop at $36^{\circ} \mathrm{C}$ water temperature as well as survey group which explain the failure of ovaries to obtain well matured ova which in turn represent another explanation for the highly significant decrease in absolute fecundity (T.R. Eggs No.) in all experimented degrees of water temperature and survey group. Thus, some ovaries showed atresia characterized by clumping and perforation of the chorion, fragmentation of nucleus, disorganization of the ooplasm and / or uptake of yolk 
material by perifollicular cells (plate $1 \mathrm{c}$ ).

Sun and Pankhurst (2004) defined testosterone (T) level to be produced by thecal cells in ovaries playing a substrate precursor of estradiol.

Throughout the three increased experimented degrees of water temperature as well as survey group fish registered highly significant increase in testosterone (T) level which was approved by Taghizadeh et al. (2013) who observed the highest of testosterone level in summer season, this increase in testosterone in the plasma could be associated with the increase in the water temperature which occurs at the summer season. Temperature appears to be a possible cue causing testosterone to peak which leads to the gonads, and subsequently their gametes, reaching reproductive maturity.

\section{References:}

Al-Deghayem Waleed A, Hamoud F. Al-Balawi, Saleh A. Kandeal and El Amin M. Suliman (2017).

Gonadosomatic index and some hematological parameters in African catfish Clarias gariepinus (Burchell, 1822) as affected by feed type and temperature level, BRAZILIAN ARCHIVES OF BIOLOGY AND TECHNOLOGY, Vol.60 , ISSN 1678-4324.
Andreeva A. M. (2010). Structure of Fish Serum Albumins, Journal of Evolutionary Biochemistry and Physiology, Vol. 46, No. 2, pp. $111-118$.

Baker,M.E. (2002) .Albumin ,steroid hormones and the origin of vertebrates . Journal of Endocrinology 175, 121-127.

Barannikova .A, Bayunova .L.V and Semenkova .T.B, (2004): Serum levels of testosterone, 11-ketotestosterone and oestradiol-17 $\beta$ in three species of sturgeon during gonadal development and final maturation induced by hormonal treatment. Journal of fish Biology : 1330-1338.

Baras E, Jacobs B, Melard C (2001). Effect of water temperature on survival, growth and phenotypic sex of mixed (XX-XY) progenies of Nile tilapia Oreochromis niloticus. Aquaculture 192: 187-199.

Biswas AK, Seoka M, Takii K, Maita M, Kumai $\mathbf{H}$. (2002).Stress response of red sea bream Pagrus major to acute handling and chronic photoperiod manipulation. Aquaculture; 252: 566-572.

Dagzie, M. (1982). Species combination in Tilapia culture. Aquaculture, 27: 295- 299.

\section{Datta Surjya Narayan,} Vaneet Inder Kaur, Asha 
Dhawan, and Geeta Jassal (2013). Estimation of lengthweight relationship and condition factor of spotted snakehead Channa punctata (Bloch) under different feeding regimes, Springerplus. 2: 436.

El-Ashram, M. A. (1999): Some reproductive studies one some freshwater fish with regard to some pathological and toxicological factors. Ph. D. Thesis of Obstetrics, Gynaecology and A. I. Fac. of Vet. Med. Zagazig Univ. Egypt.

Gerking, S. D. (1978): Ecology of fresh water fish production. Ph.D. Dept. of Zool. Arizona Univ., U.S.A.

Getso, B.U., Abdullahi, J.M. and Yola, I.A (2017). Lengthweight relationship and condition factor of clarias gariepinus and oreochromis niloticus of wudil river, kano, Nigeria . Journal of Tropical Agriculture, Food, Environment and Extension, Volume 16 Number 1,pp. 1 4.

Gonzalez, C. E. (1997). La Piscicultura en Colombia: Technologia de Punta enEl Departamento del Valle del Cauca". Pp. 78-84 in D. E. Alston, B. W.Green and H. C. Clifford, editors, IV symposium on aquacult. in
CentralAmerica: focusing on shrimp and tilapia, 22-24 April, Tegucigalpa,Honduras.

Asociacion Nacional de Acuicultores de Honduras and theLatin American Chapter of the World Aquacult. Society.

Hughes, D.G. and Behrends, L.L. (1983). Mass production of Tilapia niloticaseed in suspended net enclosures. International Symposium on Tilapia inAquacult. Proceedings Nazareth Israel, May 8-13: 394-401.

Jeremy S. Likongwe , Timothy D. Stecko, Jay R. Stauffer , Jr. , Robert F. Carline (1996). Combined effects of water temperature and salinity on growth and feed utilization of juvenile Nile tilapia Oreochromis niloticus (linneaus). Aquaculture 146, 37-46.

Jisr Nazek, GhassanYounes, CarolSukhn , Mohammad H.El-Dakdouki (2018). Length-weight relationships and relative condition factor of fish inhabiting the marine area of the Eastern Mediterranean city, Tripoli-Lebanon, The Egyptian Journal of Aquatic Research Volume 44, Issue 4, Pages 299-305.

Jin Shaofei, Xiaodong Yan, Heng Zhang and Wei Fan (2015).

Weight-length relationships and Fulton's 
condition factors of skipjack tuna (Katsuwonus pelamis) in the western and central Pacific Ocean ,PeerJournal 3:758

Khater El-Sayed G , Ali Samir A and Mohamed Waheed E (2017). Effect of Water Temperature on Masculinization and Growth of Nile Tilapia Fish, J Aquac Res Development, Volume 8 - Issue 9:507

\section{Kovyrshina Tatyana B.,} Rudneva Irina I. (2012). Comparative study of serum albumin levels in round goby neogobius melanostomus from black sea and azov sea, International journal of advanced biological research, VOL. 2(2) 203-208.

Kumar Sullip Majhi, Sanjay Kumar Das and Dipjyoti Rajkhowa (2013). Effects of elevated water temperature on tolerance and stress in Chocolate mahseer Neolissochilus hexagonolepis: implications for habitat restorationand conservation, JOURNAL ARTICLE Current Science Vol. 105, No. 3, pp. 379-383.

\section{López . H, J. R.; Hernández-} Rodríguez, M.; RivasManzano, P. \& BückleRamirez, L. F.(2018). Thermal effect of acute and chronic stress on hepatic and renal tissue of the Pacific Sardine,
Sardinops sagax caeruleus (Jenyns, 1842). Int. J. Morphol., 36(1):212-220.

Lovshin, L. L. (1997). Worldwide Tilapia Culture". in Anais do I WorkshopInternational de Aquicult., October 15-17, 96116. Sao Paulo, Brazil.

Lucas Pedro Gonçalves Junior , Cristiano Campos Mattioli,_Edenilce de Fátima Ferreira Martins, Walisson de Souza e Silva,Tarso Natividade Ciolete,_Angélica da Silva Vasconcellos, Ronald Kennedy Luz.(2019), Temperature-induced changes in reproductive variables in the teleost fish Lophiosilurus alexandri, journal of Thermal Biology, Volume 80, 2019, pp. 133-140.

Mahmoud, T.H. and Allam,S.M. (2002): Heavy metals ,protein and lipid concentration in muscles, liver and gonads of Boops boops . J. Egypt.Ger .Soc .Zool .37 (A):225 -242.

Malavasi, S., Fiorin, R., Franco, A., Torricelli, P. (2004): Somatic energy storage and reproductive investment in the grass goby Zosterisessor ophiocephalus. J. Mar. Biol. Assoc. UK 84, 455-459.

Malini D. M, Madihah , Apriliandri A. F and Arista $S$ (2018). Increased Blood 
Glucose Level on Pelagic Fish as Response to Environmental Disturbances at East Coast Pangandaran, West Java, Earth and Environmental Science 166.

Moustafa, S. E. (1999): Effect of some insecticides on freshwater fish. Ph. D. Pharma., Zagazig Univ. Egypt.

Nadirah Musa, Hazza R. Ramly, Mohammad T. Abdul Manaf , Laith A. Razzak, , Najiah Musa (2017). High water temperature impairs physiological responses in red hybrid tilapia: effects on cortisol and its regulation. AACL Bioflux, Volume 10, Issue 5.

Nakanon, Masumi Kameda, Yui Shoji, Satoshi Hayashi, Toshiyasu

Yamaguchi,Minoru Sato (2014). Effect of severe environmental thermal stress on redox state in salmonToshiki ,(Redox Biology 2) 772-776.

Nashwa Elias N. S. and Abdel-halim .S.S (2009): Effect of Hydrogen Ion Concentration $(\mathrm{PH})$ fluctuation on bacterial infections and fecundity of $O$. niloticus, Abassa International journal for Aquaculture, special Issue for global fisheries and aquaculture Research conference.pp 819834.
Pandit N.P. and Nakamura M.(2010): Effect of High Temperature on Survival, Growth and Feed Conversion Ratio of Nile Tilapia, Oreochromis niloticus , Our Nature 8:219-224

Pankhurst, N.W. \& Porter, M.J.R. (2003). Cold and dark or warm and light: variations on the theme of environmental control of reproduction. Fish Physiology and Biochemistry 28, 385-389.

Ray S.N.C. and Sinha R.C. (2014). Serum Cortisol and Glucose: Reliable Bioindicators of stress in the Fish Labeo rohita , International Journal of Innovative

Science, Engineering \& Technology, Vol. 1 Issue 8.

Rebl, Marieke Verleih, Mareen Nipkow, Simone Altmann, Ralf Bochert, and Tom Goldammer (2018). Gradual and Acute Temperature Rise Induces Crossing Endocrine, Metabolic, and Immunological Pathways in Maraena Whitefish (Coregonus maraena) Alexander, Frontiers in Genetics. 2018; 9: 241.

Shakweer, L. M. and Abbas, M. M. (2006). Effect of sex on the concentrationlevels of some trace metals in Oreochromis niloticus of Lake Edku and Sardinella aurita of the 
Mediterranian waters, Egypt. Bull. Nat. Inst. Of Oceanogr. \& Fish. 22: 121-141.

Sherif A.H and Soad S.A. Salama (2013), Heat Stress Effect on Some Bacterial Infection in Oreochromis niloticus,

Silver A .Michael and Shenk Wilbur D. Chesapeake (1968).

Temperature

Dependence of Glucose Concentration in Toadfish Blood, Journal Article Science Vol. 9, No. 1 ,pp. 1-8.

SPSS 14(2006): Statistical package for social science, SPSS for windows release 14.0.0,12 june ,2006. standard version, copyright SPSS Inc., 1989-2006. All Rights Reserved, copyright (R) SPSS Inc.

Sulistyo ,I ; Fontaine , P; Rinchard ,J: Gardeur, J; Migaud ,H; Capdeville, $\mathrm{B}$. and Kestemont ,P.(2000): Reproductive cycle and plasma levels of steroids in male Eurasian perch .Aquat .Livi . Res., 13(2):99-106.

Sun, B. and Pankhurst, N. W. (2004): Patterns of oocyte growth, vitellogenin and gonadal steroid concentrations in greenback flounder. J. Fish Biol., 64: 1399-1412.

Taghizadeh

Vahid, Mohammad Reza Imanpoor and Nooshin Mehdinejad (2013). Study the seasonal steroid hormones of common carp in Caspian Sea, Iran; Springer plus 2: 193.

Takashima, F. and Hibiya, T. (1995): An atlas of fish histology. Normal and pathological features. $2^{\text {nd }} e d$. Kodansha Ltd. Tokyo, Stuttgart and New York.

Tietz, N, W. (1995 a): Clinical Guide to laboratory Tests, 3rd Edition, W. B Saunders. Co, Philadelphia: 268-273.

Tietz, N, W. (1995 b): Clinical Guide to laboratory Tests, 3rd Edition, W.B Saunders .Co, Philadelphia: 578-580.

Tietz, N, W. (1995 c): Clinical Guide to laboratory Tests, 3rd Edition, W.B Saunders .Co, Philadelphia: 216-217.

Young, DS (1995): Effect of drugs on clinical laboratory tests, 4th edition AACC press.

Zakia .A. M.Ahmed; Gehan .Z .Moustafa .; W. Anwer and S.T.Moubarak (2007). Effect of aquarium heat stress on performance of nile tilapia and water quality, J. Egypt. Vet. Med. Assoc, 67 No.1.

Zaragoza Oscar Del Río ,Mónica Hernández Rodríguez and Luis $F$. Bückle Ramirez (2008). Thermal stress effect on tilapia Oreochromis mossambicus 
(Pisces: Cichlidae) blood parameters, Journal Marine and Freshwater Behaviour and Physiology, Volume 41, Issue 2 Pages 79-89.

\section{Zeynep Dengiz Balta,} Süleyman Akhan, Fikri Balta (2017). The physiological stress response to acute thermal exposure in Black Sea trout (Salmo trutta labrax Pallas, 1814), Turkish Journal of

Veterinary and Animal

Sciences, 41: 400-406

Zvavahera,

C.C.,

Hamandishe, V.R., Saidi, P.P., Saidi, P.T., Imbayarwo, V.E., Nhiwatiwa, T. (2018). Modification of the Oreochromis Spp. Aquaculture Production Environment Using Greenhouses. Journal of Aquaculture Engineering and Fisheries Research, 4(2), 64-72.

\section{تأثير تقلبات درجة حرارة المياه علي الحالة الصحية والتكاثر في إناث} البالطي النيلي الني النياه

إسماعيل عبد المنعم عيسى ، نثوى سمير إلياس ، منى محمود إسماعيل ،رحمة حسين عيد

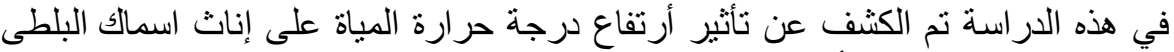

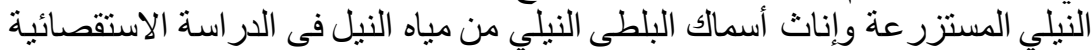

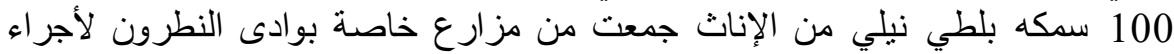

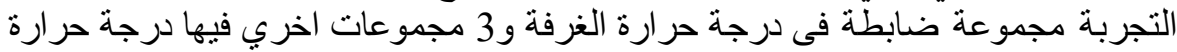

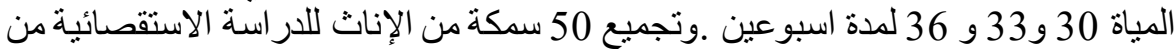

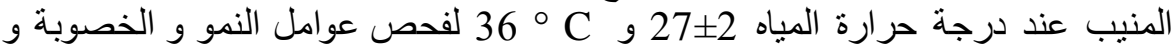

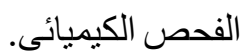

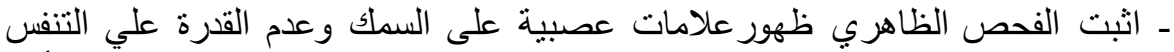
والحركة بطريقة غير طبيعية و صبغات و تقرحات على الجلد مع وتساقط القشور و و وتأكل

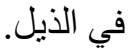
ـ وقد تبين من الصفة التشريحية وجود احتقان وتضخم فى المبيض مع وجود عدم تماثل في

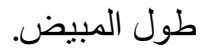
ـ سجلت الاناث فى وزن الجسم و أوزان المناسل و وزن الكبد و معامل التغير في المناسل

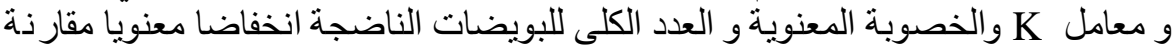

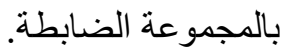

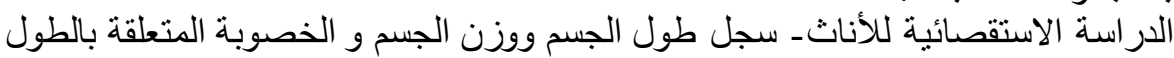

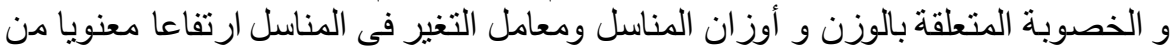

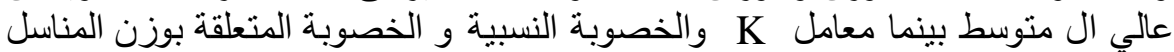

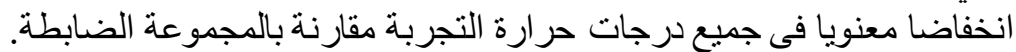

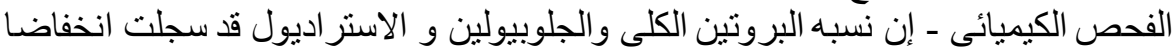
معنويا فى الاناث والدراسة الاستقصائية مقارنة بالمجموعة الضابطة الانية 
ـ الجلوكوز و التستستيرون سجل ارتفاعا معنويا في الإناث فى جميع درجات حرارة التجربة و الدراسة الاستقصائية ـ الالبيومين 33 و36 درجة للأناث سجلت الخفاضا معنويا وفي درجة 30 سجلت ارتفاعا ـ أوضح الفحص الهستولوجى للمبيض وجود مساحات من النكرزة واترشيا والتي تتميز

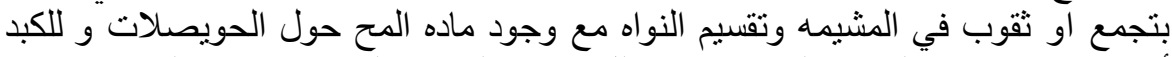

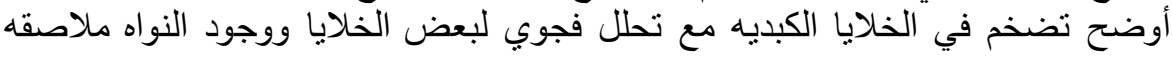
لجدار الخليه. كذلك وجود درجات مضاعفه من النكرزه في القناه بين الكبد والبنكرياس. 